\title{
Historiografia polska przełomu XX/XXI stulecia wobec Zagłady Żydów oraz stosunków polsko-żydowskich. Zarys problematyki
}

Badania nad Zagładą Żydów rozpoczęto na terenie Polski jeszcze przed ostatecznym zakończeniem II wojny światowej. Zostały one zainicjonowane już w kilka tygodni po wkroczeniu Armii Czerwonej na teren obecnego państwa polskiego ${ }^{1}$. W tym pierwszym okresie skupiano się głównie na gromadzeniu źródeł dotyczących polityki ludnościowej III Rzeszy na okupowanych ziemiach polskich i zbierano relacje naocznych świadków. Część z zebranej wówczas dokumentacji była następnie publikowana przez ośrodki naukowo-badawcze ${ }^{2}$, zarówno jako edycje źródeł, wspomnienia, opracowania naukowe lub artykuły. Z tematów podejmowanych do połowy lat sześćdziesiątych XX w. przeważały przede wszystkim monografie obozów koncentracyjnych oraz los Żydów pod okupacją niemiecką i martyrologia ludności polskiej. Do końca lat osiemdziesiątych XX w. dzieje Żydów i Polaków traktowane były jednak jako dwie odrębne sprawy bez uwzględnienia wzajemnego przenikania się w czasie wojny losów jednego i drugiego narodu³

J. Tomaszewski, Historiografia Polska o Zagładzie, „Biuletyn Żydowskiego Instytutu Historycznego" 2000, nr 2 (194), s. 155. Zob. też: N. Aleksiun, Historiografia na temat Zagłady i stosunków polsko-żydowskich w okresie drugiej wojny światowej, „Zagłada Żydów. Studia i Materiały”, Pismo Centrum Badań nad Zagładą Żydów Instytutu Filozofii i Socjologii Polskiej Akademii Nauk, red. B. Engelking, J. Grabowski, D. Libionka, J. Leociak, Warszawa 2005, nr 1, s. 32-51.

2 Wśród nich można wymienić Centralną Żydowską Komisję Historyczną przekształconą w 1947 r. w Żydowski Instytut Historyczny (funkcjonujący pod tą nazwą do czasów obecnych ŻIH), Poznański Instytut Zachodni, Główną Komisję Badania Zbrodni Niemieckich w Polsce (w 1949 r. przekształconą w Główną Komisję Badania Zbrodni Hitlerowskich) - GKBZH. Od 2000 r. jej kontynuatorem o rozszerzonej znacznie działalności jest Instytut Pamięci Narodowej Komisja Ścigania Zbrodni przeciwko Narodowi Polskiemu (IPN-KŚZpNP).

3 Na temat interpretacji losów Żydów i Polaków w czasie II wojny w polskiej historiografii zob. L. Dobroszycki, polska historiografia na temat zagłady: przegląd literatury i próba syntezy, [w:] Holocaust z perspektywy pótwiecza. Pięćdziesiąta rocznica powstania w getcie warszawskim, Materiały z konferencji zorganizowanej przez żydowski Instytut Historyczny w dniach 29-31 marca 1993, red. D. Grinberg, P. Szapiro, Warszawa, b.d.w., s. 180-183. 
Nie sposób szczegółowo przedstawić stan polskiej historiografii dotyczącej Zagłady Żydów i stosunków polsko-żydowskich w jednym artykule, ponieważ w chwili obecnej jest ona ogromna ${ }^{4}$. Mam tu na myśli prace zarówno polskich historyków, jak przedstawicieli innych dyscyplin naukowych wydane w kraju i poza jej granicami oraz tłumaczenia na język polski prac naukowców zagranicznych. W tym artykule skupię się przede wszystkim na ukazaniu dorobku polskich historyków, ponieważ właśnie on jest w tym przypadku najbogatszy ${ }^{5}$. Są to zarówno publikacje źródłowe, opracowania naukowe, wspomnienia z czasów zagłady, a także publicystyka. Jest ona obecnie publikowana przez kilkanaście ośrodków naukowo-badawczych, które zajmują się szeroko pojętą problematyką Zagłady Żydów lub w swoich badaniach uwzględniają również tą problematykę.

Od końca XX w. ukazała się duża liczba opracowań poświęconych w węższym lub szerszym zakresie zagładzie Żydów. Wśród nich są zarówno prace, które zawierają ogólne spojrzenie na proces przygotowania i mechanizm eksterminacji ludności żydowskiej w czasie II wojny ${ }^{6}$, jak i studia regionalne poświęcone zagładzie skupisk żydowskich w poszczególnych regionach lub miejscowościach okupowanej Polski . Opracowania taktujące o funkcjonowaniu gett koncentrują się głów-

$4 \quad$ Zob.: J. Tomaszewski, op. cit.; N. Aleksiun, op. cit., nr 1, s. 32-51.

$5 \quad$ Z zagadnień dotyczących Zagłady spoza obszar badań historycznych lub z ich pogranicza zob. np.: M. C. Steinlauf, Pamięć nieprzyswojona. Polska pamięć Zagłady, z oryginału przeł. A. Tomaszewska, Warszawa 2001; Zrozumieć Zagładę. Społeczna psychologia Holocaustu, red. L. S. Newman, R. Erber, z oryginału przeł: M. Budziszewska, A. Czarna, E. Dryll, A. Wójcik, Warszawa 2009; Z. Bauman, Nowoczesność i Zagłada. Holocaust - choroba czy produkt cywilizacji? z oryginału przeł. T. Kunz, Warszawa 2009; M. Melchior, Zagłada i stosunki polsko-żydowskie w opracowaniach socjologicznych, ,Zagłada Żydów. Studia i Materiały”..., Warszawa 2005, nr 1, s. 52-72; B. Engelking, Sny jako źródło do badań nad Zagłada, „Zagłada Żydów. Studia i Materiały"..., Warszawa 2013, nr 9, s. 19-47.

6 Ch. R., Browning, Geneza „ostatecznego rozwiazania”. Ewolucja nazistowskiej polityki wobec Żydów. Wrzesień 1939-marzec 1942, z oryginału przeł. B. Gutowska-Nowak, Kraków 2012; M. Gilbert, Atlas historii Holocaustu, z oryginału przeł. M. Klimowicz, Kraków - Kryspinów, b.r.; S. Friedländer, Czas eksterminacji. Nazistowskie Niemcy i Żydzi 1939-1945,z oryginału przeł. S. Kupisz; A. M. Nowak, K. Masłowski, Warszawa 2010; D. Silberklang, Refleksje na temat losu Żydów w okupowanej Polsce 1939-1945, przeł. A. Matulewska, „Pamięć i Sprawiedliwość” Pismo naukowe poświęcone historii najnowszej, 2008, nr 1(12), s. 113-125; R. Hilberg, Zagłada Żydów europejskich, z oryginału przeł. J. Giebułtowski, Warszawa 2014, t. 1-3. Zob. też: J. Giebułtowski, Niech przemówia fakty. O polskim wydaniu Zagłady Żydów europejskich Raula Hilberga „Zagłada Żydów. Studia i Materiały”, Warszawa 2013, nr 9, s. 656-660.

7 Zob. np.: A. Potocki, Żydzi rymanowscy, Krosno 2000; S. Szymańska, Ludność żydowska w Otwocku w czasie II wojny światowej, Warszawa 2002; Zagłada Żydów Zagtębiowskich, red. A. Namysło, Będzin 2004; E. Rączy, I. Witowicz, Zagłada Żydów na Rzeszowszczyźnie. Album pamięci. (Extermination of Jews in the Rzeszów Region, Rzeszów-Warszawa 2004; K. Urbański, Zagłada Żydów w dystrykcie radomskim, Kraków 2004; A. Kopciowski, Zagłada Żydów w Zamościu, Lublin 2005, Prowincja noc. Życie i zagłada Żydów w dystrykcie warszawskim, red. B. Engelking, J. Leociak, D. Libionka, Warszawa 2007; J. A. Młynarczyk, Judenmord in Zentralpolen. Der Distrikt Radom im Generalgouvernement 1939-1945, Darmstadt 2007; Zagłada Żydów na 
nie na dużych miastach, leżących na obszarze Polski w obecnych jej granicach, jak np. Kraków, Lublin, Łódź czy Warszawa. Nadal brak studiów poświęconych dzielnicom żydowskim na wschodnich obszarach byłej Rzeczypospolitej. Najlepiej z nich opracowane jest dotąd getto we Lwowie. Wciąż natomiast nie ma całościowego opracowania poświęconego historii gett w okupowanej Polsce z uwzględnieniem życia codziennego, ruchu oporu i ostatecznego losu ich mieszkańców ${ }^{8}$.

Kolejnymi wątkami związanymi z życiem Żydów pod niemiecką okupacją, które od XXI w. szerzej podejmują polscy historycy to żydowskie władze (zarówno administracja cywilna, jak i siły porządkowe w gettach) ${ }^{9}$. Wśród historyków toczy się polemika o postawy policjantów żydowskich i przywódców Judenratów wobec Niemców i swoich rodaków. W związku z brakiem odpowiedniej dokumentacji sprowadza się ona głównie do analizowania działań komendantów policji, przewodniczącego Żydowskiej Samopomocy Społecznej Michała Weicherta oraz przewodniczących największych skupisk Żydów w okupowanej Polsce, którzy odcisnęli swój ślad na życiu tysięcy ludzi (Chaima Mordechaja Rumkowskiego z Łodzi, Jakuba Gensa z Wilna, Efraima Barasza z Białegostoku, Mojżesza Merina ze Śląska i Adama Czerniakowa z Warszawy ${ }^{10}$. Informacje o nich przewijają się w opracowaniach dotyczących sytuacji Żydów w poszczególnych regionach okupowanego kraju. Nadal brak jest jednak opracowań naukowych stricte im poświęconych, które brałyby również pod uwagę całą złożoność wojennej sytuacji, w jakiej przyszło im działać. Wyjątek stanowią dwaj przewodniczący: Adam Czerniaków

polskich terenach wcielonych do Rzeszy, red. A. Namysło, Warszawa 2008; A. Krempa, Zagłada Żydów mieleckich, Mielec 2012; J. Kazimierski, Ludność żydowska w Warszawie w latach 19391943. Życie-walka-Zagłada, Warszawa 2012; E. Rączy, Zagłada Żydów w dystrykcie krakowskim 1939-1945, Rzeszów 2014; K. Przybyłowicz, Żydzi Biecza. Historia i Zagłada, Gliwice-Libusza 2015; G. Berendt, Rewolta więźniów getta w Eachwie (3 września 1942), Pismo społeczno-historyczne „Glaukopis” (dalej: „Glaukopis”) 2011-2012, nr 23-24; idem, Opór i zagłada żydowskiej ludności Turczyna (24 września 1942 r.), „Glaukopis” 2012, nr 25-26, s. 44-52; K. Lesiakowski, Z dziejów Zagłady w Kraju Warty. Losy ludności żydowskiej w Sieradzu 1939-1942, „Pamięć i Sprawiedliwość". Pismo naukowe poświęcone historii najnowszej, Warszawa 2014, nr 1 (23), s. 247-266.

8 Opracowanie Głównej Komisji Badania Zbrodni Hitlerowskich w Polsce i Rady Pamięci Walk i Męczeństwa, Obozy hitlerowskie na ziemiach polskich 1939-1945. Informator encyklopedyczny, wydany w Warszawie w 1979 r. nie uwzględnia wschodnich obszarów byłej Rzeczpospolitej, a część umieszczonych tam informacji wymaga weryfikacji.

9 Z ostatnich pozycji na ten temat warto wymienić: A. Sitarek, Otoczone drutem państwo. Struktura i funkcjonowanie administracji żydowskiej getta łódzkiego, Łódź 2015.

10 Por: J. Szczęsna, Reduta Adama Czerniakowa, „Gazeta Wyborcza” 21-22 IX 2002; W. Stanisławski, T. Terlikowski, Rumkowski, Czerniaków - życiorysy równolegle, „Życie” 2004, 14 października; A. Namysło, Centrala żydowskich Rad Starszych na Wschodnim Górnym Ślasku [w:] Zagłada Żydów Zagłębiowskich..., E. Kurek, Poza granice solidarności. Stosunki polsko-żydowskie 1939-1945, Kielce 2006; D. Michman, O okolicznościach ustanowienia warszawskiego Judenratu. Nowy punkt widzenia, „Kwartalnik Historii Żydów” 2007, nr 1; J. Baranowski, Chaim Mordechaj Rumkowski - kolaborant czy zbawca?, [w:] Zagłada Żydów na polskich terenach wcielonych do Rzeszy..., s. 169-175. 
i Mordechaj Chaim Rumkowski. Ich biografie stanowią ważny głos w toczącej się od wielu lat dyskusji ${ }^{11}$.

W XXI w. także szerzej poruszona została w polskiej historiografii sprawa negatywnych postaw samych Żydów wobec swoich rodaków. Do tej pory temat ten sygnalizowany był zazwyczaj przy omawianiu innych zagadnień związanych z Zagładą czy ogólnie kolaboracją, rzadziej natomiast poświęcało się mu osobne opracowania $^{12}$. Wydaje się, że wpływ na to miało kilka czynników. Jednym z nich jest stosunkowo niewielka ilość odpowiednich źródeł. To co znajduje się w archiwach polskich nie jest wystarczające do syntetycznego opracowania tak skomplikowanego zagadnienia, które objęłoby obszar całej okupowanej Polski. Z kolei bariera językowa (źródła w języku hebrajskim) zdecydowanie utrudnia skorzystanie z pełnej dokumentacji sądowej znajdującej się w Izraelu, gdzie po wojnie wytaczano procesy osobom oskarżanym o negatywne zachowania. Kolejnym wydaje się być bariera emocjonalna. Kolaboranci żydowscy w polskiej historiografii byli przez długi czas przemilczani, a obecnie traktowani są raczej, jako ofiary sytuacji okupacyjnej. Stosunkowo rzadko uwzględnia się fakt, że pewna część z nich trudniła się takim procederem także dla osobistej korzyści. Niewiele także ukazało się w języku polskim wspomnień uratowanych z Holocaustu, którzy opisywali takie działania Żydów ${ }^{13}$. Dopiero 2014 r. z inicjatywy Żydowskiego Instytutu Historycznego wydany został wybór źródeł poświęcony powojennym rozliczeniom z żydowskimi kolaborantami w Polsce powojennej ${ }^{14}$.

11 M. Urynowicz, Adam Czerniaków 1880-1942. Prezes getta warszawskiego, Warszawa 2009; M. Polit, „Moja żydowska dusza nie obawia się dnia sq̨du”. Mordechaj Chaim Rumkowski. Prawda i zmyślenie, Warszawa 2012.

12 Wśród tych, którzy podjęli temat kolaboracji żydowskiej zob. np.: W. Mędykowski, Przeciw swoim. Wzorce kolaboracji żydowskiej w Krakowie i okolicy, „Zagłada Żydów. Studia i Materiały”... Warszawa 2006, nr 2, s. 202-220; B. Tal, Sqqdzenie tych, którzy nie mogli być sqqdzeni. Procesy kolaborantów w Izraelu, „Zagłada Żydów. Studia i Materiały”..., Warszawa 2006, nr 2, s. 99-131; M. J. Chodakiewicz, Lonek Skosowski: Koniec żydowskich kolaborantów Gestapo, „Glaukopis 2007-2008, nr 9-10, s. 325-333; Z. Bauman, Nowoczesność i Zagłada..., s. 300-313; J. A. Młynarczyk, pomiędzy wspótpraca, a zdradq. Problem kolaboracji w Generalnym Gubernatorstwie - próba syntezy, „Pamięć i Sprawiedliwość” 2009, nr 1(14); B. Engelking, J. Grabowski, „Żydów tamiących prawo należy karać śmiercia!’”. „Przestępczość Żydów w Warszawie 1939-1942”, Warszawa 2010; M. Paul, Donosiciele i szabrownicy w okupowanej Warszawie (1939-1944), „Glaukopis” 2012, nr 27, s. 126-153; M. Urynowicz, Adam Czerniaków..., s. 285-291; E. Rączy, Zagłada Żydów w dystrykcie krakowskim 1939-1945, Rzeszów 2014, s. 216-229.

13 Zdecydowana większość z nich wydana została poza granicami Polski. W polskim tłumaczeniu ukazały się m.in. Y. Cukierman (Antek), Nadmiar pamięci (siedem owych lat): Wspomnienia 1939-1946, przeł. Z. Perelmuter Warszawa 2000; R. A. Cyprys, Skok dla życia: Pamiętnik z czasów okupacji, Warszawa 2001, tłum. z angielskiego E. Skweres; E. Ernest, O wojnie wielkich Niemiec z Żydami w Warszawie 1939-1943, Warszawa 2003, oraz wznowienie wspomnień C. Perechodnika, Spowiedź, Warszawa 2011.

14 A. Żbikowski, Sąd Społeczny przy CKŻP. Wojenne rozliczenie społeczności żydowskiej w Polsce, Warszawa 2014. 
W ostatnich latach w kręgu zainteresowania historyków polskich znalazły się obozy zagłady (przede wszystkim Bełżec, Sobibór i Chełmno nad Nerem). Przez długi okres ich historia nie tylko w Polsce, ale także poza granicami była słabo rozpoznana ${ }^{15}$. Wyjątkiem w tym był obóz zagłady w Treblince ${ }^{16}$. Dopiero na przełomie XX i XXI w. powstały całościowe opracowania poświęcone historii tych obozów zagłady ${ }^{17}$. Nadal jest także uzupełniana wiedza dotycząca losu więźniów żydowskich w obozach koncentracyjnych, obozach pracy przymusowej i obozach przejściowych funkcjonujących na terenach okupowanej Polski, a także tych, które po II wojnie w wyniku zmiany granic, znalazły się w obrębie naszego kraju ${ }^{18}$.

Nadal w zainteresowaniu historyków pozostają więźniowie żydowscy w obozach koncentracyjnych, nawet $\mathrm{w}$ tak dobrze przebadanych, w porównaniu $\mathrm{z}$ wieloma innymi, jak KL Auschwitz-Birkenau, Majdanek czy Stutthof. W drugiej połowie lat dziewięćdziesiątych XX w. Muzeum Auschwitz-Birkenau opublikowało spisy więźniów tego obozu zapisanych w „księgach zgonów” (Sterbebücher von Auschwitz) od końca lipca 1941 do końca $1943^{19}$. Zawierają one łącznie dane osobowe 68864 ludzi zmarłych i zamordowanych w obozie. Wiele z nich dotyczy więźniów żydowskich pochodzących z różnych krajów europejskich. Do badań nad zagładą Żydów pozycja ta ma wyjątkowe znaczenie. W 2000 r. Muzeum zapoczątkowało z kolei serię wydawniczą poświęconą poszczególnym transportom polskich więźniów politycznych skierowanym do obozu z różnych regionów

15 D. Pohl, „Akcja Reinhardt” w świetle historiografii, [w:] Akcja Reinhardt. Zagłada Żydów w Generalnym Gubernatorstwie, red. D. Libionka, Warszawa 2004, s. 340-341.

16 Szerzej zob.: D. Pohl, op. cit., s. 341.

17 Warto tu wspomnieć m.in. A. Koli, Hitlerowski obóz zagłady w Bełżcu w świetle źródeł archeologicznych: badania 1997-1999, Warszawa-Waszyngton 2000, R. Kuwałek, Obóz Zagłady w Betżcu, Lublin 2010; M. Bem Sobibór niemiecki ośrodek zagłady 1942-1943, Włodawa - Sobibór 2011; Obóz Zagłady w Bełżcu w relacjach ocalonych i zeznaniach polskich świadków, red. D. Libionka, Lublin 2013; P. Montaque, Chetmno. Pierwszy nazistowski obóz zagłady. Z oryginału przeł. T. S. Gałązka, Warszawa 2014. Ponadto można wymienić artykuły: R. Auerbach, Treblinka. Reportaż, „Zagłada Żydów. Studia i Materiały”, red. B. Engelking, J. Grabowski, D. Libionka, J. Leociak, Warszawa 2012, nr 8, s. 27-75; C. Sturdy Colls, O tym, co minęło, lecz nie zostało zapomniane. Badania archeologiczne na terenie byłego obozu zagłady w Treblince, „Zagłada Żydów. Studia i Materiały"..., nr 8, s. 83-118; R. Kuwałek, Nowe ustalenia dotyczqce liczby ofiar niemieckiego obozu zagłady w Sobiborze, ,Zeszyty Majdanka” 2014, t. XXVI, s. 17-60.

18 J. Marszałek, Obozy pracy w Generalnym Gubernatorstwie w latach 1939-1945, Lublin 1998; M. Orski, Niewolnicza praca więźniów obozu koncentracyjnego Stutthof w latach 1939-1945, Gdańsk 1999; J. Kosiński, W. Sobczyk, Niemieckie obozy koncentracyjne i ich filie, b.m.w. 1999; D. Drywa, Zagłada Żydów w obozie koncentracyjnym Stutthof 1939-1945, Gdańsk 2001; A. Zió1kowska Obozy pracy przymusowej dla Żydów w Wielkopolsce w latach okupacji hitlerowskiej (1941-1943), Poznań 2005; B. Kopka, Koncetrationslager Warschau. Historia i następstwa, Warszawa 2007; R. Kotarba, Niemiecki obóz w Płaszowie, Warszawa - Kraków 2009.

19 Księgi zgonów z Auschwitz, red. J. Dębski, S. Goldman, H. Jastrzębska, S. Kreuhage, J. Parcer, Oświęcim 1995, t. 1-3. 
okupowanej Polski ${ }^{20}$. Wśród nich znaleźć można również osoby narodowości żydowskiej, ponieważ w pierwszym okresie funkcjonowania KL Auschwitz Żydzi przywożeni byli do niego przede wszystkim w transportach z Polakami ${ }^{21}$. Oprócz danych osobowych więźniów znaleźć w nich można także informacje dotyczące ich losów w Auschwitz oraz potwierdzające to dokumenty źródłowe. W ten cykl wpisuje się także praca Stanisława Mączki poświęcona już stricte polskim Żydom deportowanym do KL Auschwitz w różnych transportach ${ }^{22}$.

Wśród prac dotyczących historii Żydów w obozach ukazała się w ostatnich latach także spora liczba tłumaczeń na język polski wspomnień i relacji byłych więźniów, którym udało się je przeżyć. Literatura wspomnieniowa, choć subiektywna, wypełnia jednak luki w naszej wiedzy na temat losu Żydów w obozach i gettach. Niektóre ze wspomnień i relacji są swoistym dokumentami pamięci. Dotyczy to zwłaszcza więźniów z komand specjalnych zatrudnionych przy obsłudze urządzeń masowej zagłady ${ }^{23}$. Szczególne znaczenie do badań nad zagładą Żydów mają także dokumenty Podziemnego Archiwum Getta Warszawskiego (tzw. Archiwum Ringelbluma). Zawierają one wiele informacji o różnych aspektach życia codziennego ludności żydowskiej na terenie okupowanej Polski. Część z tych przekazów dotyczy losu Żydów z miejscowości, o których nie zachowała żadna inna dokumentacja. Pierwszy tom materiałów z Archiwum Ringelbluma Żydowski Instytut Historyczny (ŻIH) wydał w 1997 r., a do chwili obecnej ukazało się kolejnych osiem tomów. Interesującym przyczynkiem do pierwszego z nich jest artykuł

\footnotetext{
20 Księga Pamięci. Transporty Polaków z. Warszawy do KL Auschwitz 1940-1944, Warszawa Oświęcim 2000; Księga Pamięci. Transporty Polaków do KL Auschwitz z Krakowa i innych miejscowości Polski południowej, red. F. Piper, I. Strzelecka, Warszawa - Oświęcim 2002, t. 1-5; Księga Pamięci. Transporty Polaków do KL Auschwitz z Radomia i innych miejscowości Kielecczyzny 1940-1944, red. idem, Warszawa-Oświęcim 2006, t. 1-5; Księga Pamięci. Transporty Polaków do KL Auschwitz z Lublina i innych miejscowości Lubelszczyzny 1940-1944, red. idem, Oświęcim 2009, t. 1-4.

21 Ogółem wśród 41199 osób z wyszczególnionych w ww. opracowaniach z trzech regionów Polski (kieleckiego, krakowskiego, i lubelskiego) i przywiezionych w latach 1940-1944 do KL Auschwitz było ogółem 2003 Żydów (768 z dystryktu krakowskiego, 1100 z Kielecczyzny i 135 z dystryktu lubelskiego).

22 Żydzi polscy w KL Auschwitz. Wykazy imienne, Polish Jews in KL Auschwitz. Name lists, oprac. S. Mączka, Warszawa 2004.

23 G. Greif, ,... płakaliśmy bez łez...”. Relacje bytych więźniów żydowskiego Sonderkommando z Auschwitz, z oryginału przeł. J. Kapłon, Warszawa-Oświęcim 2001; T. T. Blatt, Z popiołów Sobiboru (skąd nie ma powrotu). Historia przetrwania, Włodawa 2002; S. Venezia, Sonderkommando. W piekle komór gazowych, przeł. K. Szeżyńska-Maćkowiak, Warszawa 2009; Bunt w Sobiborze. Opowieść o przetrwaniu w Polsce okupowanej przez Niemców. Philip Bialowitz opowiada swojemu synowi Josephowi Bialowitzowi, red. naukowa R. Kuwałek, Warszawa 2008; J. Rajchman, Ocalatem z Treblinki: wspomnienia z lat 1942-1943, z oryginału przeł. B. Schwarcman-Czarnota; A. Peczerski, Szturm w nieśmiertelność. Wspomnienia, Warszawa 2013; M. A. Cywiński, Zagłada w pamięci więźniów Sonderkommando, Oświęcim 2015.
} 
M. Urynowicza poświęcony metodom maskowania informacji zawartych w listach skazanych na zagładę ludzi ${ }^{24}$.

Warto także wspomnieć, że w ostatnich czasach ukazywały się także dość licznie opracowania i biografie osób oraz formacji (lub ich przekłady na język polski), które w różnym stopniu były odpowiedzialne za dokonane na Żydach zbrod$n^{25}{ }^{25}$. Warto wśród nich wymienić raporty osób, które nadzorowały likwidowanie gett, jak np. Jürgena Stroopa czy Friedricha Katzmannna ${ }^{26}$.

Kolejnymi ważnymi publikacjami do badań nad Holocaustem są także przewodniki archiwalne. Najważniejsze z nich to wydany przez ŻIH inwentarz ze zbiorów relacji ocalonych z Holocaustu znajdujących się w jego zasobach (ponad 7290 relacji zbieranych od września 1944 r., głównie w języku polski, rzadziej w jidysz, niemieckim i rosyjskim $)^{27}$ oraz źródła do badań dziejów Żydów na okupowanych ziemiach polskich ${ }^{28}$.

Nadal jednak wiele różnych aspektów zagłady Żydów pozostaje poza głównym nurtem zainteresowań historyków. Dopiero od niedawna podejmowane i weryfikowane są zagadnienia związane z żydowskim ruchem oporu ${ }^{29}$ oraz ekonomicznymi uwarunkowaniami Zagłady Żydów ${ }^{30}$ na okupowanych ziemiach polskich. Do

24 M. Urynowicz, Listy o Zagładzie. Kryptoinformacja, „Pamięć i Sprawiedliwość” Pismo naukowe poświęcone historii najnowszej 2002, nr 1 (1), s. 121-131.

25 Ich liczba jest duża, a poziom merytoryczny różny. Warto jednak wymienić wśród nich m.in. książki: D. J. Goldhagen, Gorliwi kaci Hitlera. Zwyczajni Niemcy i Holocaust, z oryginału przeł. W. Horabik, Warszawa 1999; G. Serena, W stronę ciemności. Rozmowy z komendantem Treblinki, z oryginału przeł. J. K. Milencki, Warszawa 2002; Ch. R. Browning, Zwykli ludzie. 101 Policyjny Batalion Rezerwy I "ostateczne rozwiazanie” w Polsce, z oryginału przeł. P. Budkiewicz, Warszawa 2000. Por. J.Ch. Szurek, Proces Gustava Wilhelma Trappa, ,”Zagłada Żydów. Studia i Materiały”..., Warszawa 2013, nr 9, s. 471-485; J. Böhler, K.M. Mallmann, J. Matthäus, Einsatzgruppen w Polsce, z oryginału przeł. E. Ziegler-Brodnicka, Warszawa 2009; J. Böhler, Zbrodnie Wehrmachtu w Polsce. Wrzesień 1939. Wojna totalna, Kraków 2009; B. Rieger, Odilo Globocnik. Twórca nazistowskich obozów śmierci, z oryginału przeł. J. Zaus, Poznań 2009; J. Sachslehner, Kat z listy Schindlera. Zbrodnie Amona Leopolda Götha, Kraków 2010; C. Epstein, Wzorcowy nazista. Arthur Greiser i okupacja Kraju Warty, z oryginału przeł. J. Włodarczyk, Wrocław, b.d.w.

26 F. Katzmann, Rozwiazanie kwestii żydowskiej w Dystrykcie Galicja, oprac. A. Żbikowski, Warszawa 2001; J. Stroop, Żydowska dzielnica mieszkaniowa $w$ Warszawie już nie istnieje, oprac. A. Żbikowski, Warszawa 2009.

27 Relacje z czasów Zagłady. Inwentarz, t. I-VII. Pierwszy tom ukazał się w Warszawie w 1998, a ostatni, siódmy, w 2011 r.

28 Źródła archiwalne do dziejów Żydów w Polsce, red. B. Woszczyński, V. Urbaniak, Warszawa 2001; A. Skibińska, Źródła do badań nad Zagłada Żydów na okupowanych ziemiach polskich. Przewodnik archiwalno-bibliograficzny, Warszawa 2007.

29 Zob. np.: D. Libionka, L. Weinbaum, Bohaterowie, hochsztaplerzy, opisywacze. Wokót żydowskiego Zwiqzku Wojskowego, Warszawa 2011; M. Brzeziński, Armia Izraela. Walka i opór polskich Żydów, z oryginału przeł. M. Habura, Kraków 2013.

30 Między innymi M. Dean, Gospodarka wyzysku: „warunki życia” w gettach na Kresach Wschodnich, „Zagłada Żydów. Studia i Materiały”..., Warszawa 2007, nr 3, s. 114-131; Klucze 
przebadania wciąż pozostają sprawy związane z przygotowaniem i organizacją samej „Akcji Reinhard” na terenie całego Generalnego Gubernatorstwa ze strony władz niemieckich. Badania takie powinny także objąć wykonawców „Akcji Reinhard" przynajmniej na stanowiskach kierowników referatów żydowskich i dowódców poszczególnych placówek niemieckiej policji w miastach powiatowych oraz pracowników lokalnej niemieckiej administracji cywilnej do szczebla średniego (starostów powiatowych i miejskich) ${ }^{31}$. Co ostatni także czynnie uczestniczyli w Zagładzie, wydając nakazy przesiedlania ludności do miejsc zbiorczych, biorąc też udział w naradach, na których ustalano szczegóły akcji likwidacyjnych poszczególnych gett na podległym im terenie, a następnie przygotowywali stronę administracyjną deportacji ludności żydowskiej. Niektórzy z nich osobiście mordowali Żydów. Wciąż nie ma pełnych wykazów szeroko pojętych sprawców zbrodni działających na obszarze okupowanych ziem polskich, a co za tym idzie także opracowań poświęconych ich odpowiedzialności prawnej za popełnione czyny ${ }^{32}$.

Spornym zagadnieniem, które dodatkowo wzbudza wiele emocji, nadal pozostają stosunki polsko-żydowskie w czasie niemieckiej okupacji. Pierwsze badania nad tym zagadnieniem podjęli w latach sześćdziesiątych XX w. historycy związani z Żydowskim Instytutem Historycznym (Tatiana Berenstein, Adam Rutkowski, a zwłaszcza Szymon Datner). Dołączyli do nich następnie także Michał Grynberg i Marian Fuks. Swoje ustalenia publikowali głównie w Biuletynach wydawanych

i kasa. O mieniu żydowskim w Polsce pod okupacja niemiecka $i$ we wczesnych latach powojennych 1939-1945, red. J. Grabowski, D. Libionka, Warszawa 2014.

31 Nadal jedynym w polskiej historiografii jest opracowanie Bogdana Musiała dotycząca m.in. roli w Zagładzie cywilnej administracji niemieckiej w dystrykcie lubelskim. B. Musiał, Deutsche Zivilverwaltung und Judenverfolgung im Generalgouvernement. Eine Fallstudie zum District Lublin 1939-1944, Wiesbaden 1999. Ukazało się także kilka przyczynków o różnej wartości merytorycznej. Zob. np. S. Piątkowski, Udział niemieckiej żandarmerii w eksterminacji ludności żydowskiej Generalnego Gubernatorstwa (na przykładzie pótnocno-wschodniej części dystryktu radomskiego, [w:] Zagłada Żydów na polskiej prowincji, red. A. Sitarek, M. Trębacz, E. Wiatr, Łódź 2013, s. 265-277; M. Roth, Starostowie powiatowi i zagłada Żydów w dystrykcie krakowskim Generalnego Gubernatorstwa, [w:] ibidem, s. 279-294; A. Sitarek, Rola niemieckiego zarzqdu getta w Lodzi w eksterminacji gett prowincjonalnych Kraju Warty, [w:] ibidem, s. 295-307.

32 W XXI w. ukazało się na ten temat kilka artykułów jak np.: J. Riedel, Postepowania karne $w$ Niemczech $w$ procesach o eksterminacje Żydów na polskich ziemiach wcielonych do Rzeszy. Zarys problemu [w:] Zagłada Żydów na polskich terenach wcielonych do Rzeszy..., s. 228-252; W. Lower, Sprawcy i sprawczynie Zagłady a podejście do sprawiedliwości w NRD w latach 19491963, „Zagłada Żydów. Studia i Materiały”..., Warszawa 2012, s. 237-267 [tłumaczenie i przedruk artykułu z Holocaust and Genocide Studies, 2010, nr 1]. W 2013 r. w tomie nr 9 „Zagłada Żydów. Studia i Materiały"..., Warszawa 2013, ukazało się kilka artykułów poświęconych temu zagadnieniu: A Kornblutha, Jak wielu Kainów jest wśród nas" Polski wymiar sprawiedliwości a Zagłada, 1944-1956, s. 157-172; A. V. Prusin, Polska Norymberga: siedem procesów przed Najwyższym Trybunatem Narodowym, 1946-1948, s. 116-140; K. Peterson, Mówi Jürgen Stroop. Proces likwidatora powstania w getcie warszawskim przed Sadem Wojewódzkim w Warszawie, s. 380-425 oraz J-C. Szurek, Proces Gustava Wilhelma Trappa, s. 470-487. 
przez Żydowski Instytut Historyczny, a więc trudno wówczas dostępnych szerszemu gronu czytelników. Ogółem w latach 1950-2000 w Biuletynach ŻIH ukazało się ogółem dwadzieścia artykułów i komunikatów poświęconych Polakom ratującym Żydów w czasie niemieckiej okupacji. Znacznie mniejsze zainteresowanie, z różnych zresztą powodów, wzbudzały wówczas negatywne postawy Polaków wobec Żydów. Ogólem w tym okresie w Biuletynach ŻIH ukazały się tylko cztery ${ }^{33}$ artykuły o takiej tematyce. Problematyka stosunków polsko-żydowskich pomijana była natomiast prawie zupełnie w periodykach, od ogólnopolskich, jak np. „Dzieje Najnowsze" 34 , po lokalne wydawane przez poszczególne muzea i archiwa w Polsce.

Trudno się więc dziwić, że przez wiele lat podstawą wiedzy polskich historyków o ratowaniu Żydów była dokumentacja Instytutu Yad Vashem w Jerozolimie dotycząca osób uhonorowanych tytułem Sprawiedliwy wśród Narodów Świata oraz tych, którzy starali się o jego przyznanie ${ }^{35}$. Dopiero w XXI w. w polskiej historiografii dokonał się wyraźny postęp w zakresie badań nad stosunkami polsko-żydowskimi. Niewątpliwie przełomowym wydarzeniem było wydanie w Polsce w maju 2000 r. książki Jana Tomasza Grossa, Sąsiedzi. Historia zagłady żydowskiego miasteczka ${ }^{36}$. Zapoczątkowała ona dyskusję nad postawami Polaków wobec Żydów w czasie II wojny światowej, która trwa do dziś. To zaś zaowocowało podjęciem badań nad tymi problemami ${ }^{37}$. Kolejne prace Grossa także wzbudzały wśród Polaków dużo emocji. Na przeciwległym biegunie są publikacje M. J. Chodakiewicza, które również wzbudzają liczne kontrowersyjne.

33 Sz. Datner, zbrodnie hitlerowskie na Żydach zbiegłych z gett, „Biuletyn Żydowskiego Instytutu Historycznego" 1970, nr 3 (75), s. 7-29; P. Szapiro, Prasa konspiracyjna jako źródło do dziejów stosunków polsko-żydowskich w latach II wojny światowej-uwagi, pytania, propozycje badawcze, „Biuletyn Żydowskiego Instytutu Historycznego”; A. Żbikowski, Lokalne pogromy Żydów w czerwси i lipcu 1941 roku na wschodnich rubieżach II Rzeczypospolitej, nr 2-3 (162-163), IV-IX 1992, s. 3-18; I. Gutman, Stosunki polsko-żydowskie w świetle żydowskiej historiografii i literatury, Biuletyn Żydowskiego Instytutu Historycznego” 2000, nr 1 (193), s. 3-11.

34 Dla przykładu: od 2000 do 2014 r. w „Dziejach Najnowszych” nie ukazał się żaden artykuł poświęcony tej tematyce, a jedynie pięć recenzji prac poświęconych szeroko pojętej Zagładzie Żydów (trzy z nich dotyczyły książki J. T. Grossa, Sąsiedzi. Historia zagłady żydowskiego miasteczka, Sejny 2000).

35 W 2004 r. Instytut Yad Vashem w Jerozolimie wydał książkę poświęconą Polakom uhonorowanym tytułem Sprawiedliwy wśród Narodów Świata, [oryginalny tytuł: The Encyclopedia of the Righteous Among the Nations. Rescuers of Jews during the Holocaust. Poland, red. I. Gutman]. Pięć lat później wydana ona została w języku polskim pod tytułem Księga Sprawiedliwych wśród Narodów Świata. Ratujacy Żydów podczas Holocaustu. Polska, Kraków 2009.

36 Wcześnie temat ten był podejmowany, ale nie przyniósł większego zainteresowania opinii publicznej i historyków. Zob. np.: D. A. Wrniszewscy, ... Aby żyć, „Kontakty” Łomżyński Tygodnik Społeczny 1988, nr 27 (403), s. 1, 8-9.

37 Jednym z pierwszych wyników tych badań była dwutomowa publikacja Wokót Jedwabnego, red. P. Machcewicz, K. Persak, Warszawa 2002. W pierwszym tomie znalazły się artykuły historyków, w drugim natomiast dokumenty. 
Nadal polska historiografia jest na początku drogi znalezienia odpowiedzi na pytania dotyczące całego wachlarza postaw polskiego społeczeństwa w obliczu dokonanej przez Niemców Zagłady Żydów. Opracowania i artykuły poświęcone temu zagadnieniu nadal w żaden sposób nie wyczerpują tematu. Można je najogólniej podzielić na te poświęcone ratowaniu ludności żydowskiej podczas wojny ${ }^{38}$ oraz skupiające się na negatywnych postawach ${ }^{39}$. O wiele mniej jest prac, w których znaleźć można całe spektrum postaw Polaków wobec Żydów oraz polemik ${ }^{40}$. Należy przypuszczać, że nie da się już ustalić pełnej liczby Polaków, którzy ratowali Żydów, liczby Żydów, którzy ponieśli śmierć z polskich rąk w czasie niemieckiej okupacji, czy odpowiedzieć na pytanie o skalę i przyczyny negatywnych zachowań polskich mieszkańców wobec tych, którzy starali się przeżyć po tzw. aryjskiej stronie. Wciąż istnieją spory pomiędzy historykami dotyczące także wielu innych aspektów stosunków polsko-żydowskich. Można tu wymienić m.in. rolę jaką odegrał majątek ofiar Holocaustu w stosunkach polsko-żydowskich, postawy członków polskiego państwa podziemnego do Żydów czy kościołów chrześcijańskich ${ }^{41}$. Na-

38 E. Kurek, Gdy klasztor znaczyt życie. Udział żeńskich zgromadzeń zakonnych w akcji ratowania dzieci żydowskich w Polsce w latach 1939-1945, Kraków 1992; E. Rączy, Pomoc Polaków dla ludności żydowskiej na Rzeszowszczyźnie 1939-1945, Rzeszów 2008, „Kto w takich czasach Żydów przechowuje?...” Polacy niosący pomoc ludności żydowskiej w okresie okupacji niemieckiej, red. A. Namysło, Warszawa 2009; K. Madaj, M. Żuławnik, Proboszcz z getta, Warszawa 2010; E. Rączy, I. Witowicz, Polacy ratujący Żydów na Rzeszowszczyźnie w latach 1939-1945 (Poles Rescuing Jews in the Rzeszów Region in the Years 1939-1945, Rzeszów 2011; H. Grubowska, Ta, która ratowała Żydów. Rzecz o Irenie Sendlerowej, Warszawa 2014.

39 Zob. np.: J. Grabowski, „Ja tego Żyda znam”. Szantażowanie Żydów w Warszawie 1939-1943, Warszawa 2004; A. Żbikowski, U genezy Jedwabnego. Żydzi na Kresach Pótnocno-Wschodnich II Rzeczpospolitej, wrzesień 1939-lipiec 1941, Warszawa 2006; J. Grabowski, Judenjagd. Polowanie na Żydów 1942-1945. Studium z dziejów pewnego powiatu, Warszawa 2011; B. Engelking, Jest taki piękny słoneczny dzień... Losy żydów szukających ratunku na wsi polskiej 1942-1945, Warszawa 2011; Zarys krajobrazu. Wieś polska wobec Zagłady Żydów 1942-1945, red. B. Engelking, J. Grabowski, Warszawa 2011; B. Engelking, Jest taki piękny słoneczny dzień... Losy Żydów szukających ratunku na wsi polskiej 1942-1945, Warszawa 2011, J. Grabowski, Szantażowanie Żydów: casus Warszawy 1939-1945, „Przegląd Historyczny” 2008, t. XCIX, z. 4, s. 583-601.

40 Zob. np.: Polacy i Żydzi pod okupacja niemiecka 1939-1935. Studia i materiaty, red. A. Żbikowski, Warszawa 2006. D. Libionka, Narodowa Organizacja Wojskowa i Narodowe Siły Zbrojne wobec Żydów pod Kraśnikiem - korekta obrazu, „Zagłada Żydów. Studia i Materiały”... 2011, nr 7 , s. 28-29; B. Wolniewicz, Fikcyjne 10\% czyli ilu Żydów zabili Polacy?, „Glaukopis” 2012, nr 25-26, s. 117-120; ibidem, M. Paul, Polskie podziemie a Żydzi. Korekta obrazu s. 103-116.

${ }_{41}$ Zob. np.: A. Puławski, Postrzeganie żydowskich oddziałów przez armię Krajowa i Delegature Rzq̨du na Kraj „Pamięć i Sprawiedliwość” 2003, nr 2, s. 271-300; D. Libionka, „Kwestia żydowska" w Polsce w ocenie Delegatury Rzqdu RP i KG ZWZ-AK w latach 1942-1944, [w:] Zagłada Żydów. Pamięć narodowa a pisanie historii w Polsce $i$ we Francji, red. B. Engelking, j. Leociak, D. Libionka, A. Ziębińska-Witek, Lublin 2006, s. 41-56; D. Libionka, Narodowa Organizacja Wojskowa i Narodowe Siły Zbrojne wobec Żydów pod Kraśnikiem - korekta obrazu, „Zagłada Żydów. Studia i Materiały”... 2011, nr 7, s. 28-29; D. Libionka, Narodowa organizacja Wojskowa i Narodowe Sity Zbrojne wobec Żydów pod kraśnikiem - korekta obrazu, „Zagłada Żydów. Studia 
dal nie ma opracowań poświęconych stosunkowi do Żydów administracji niższego szczebla (wójtów, sołtysów) oraz funkcjonariuszy formacji pomocniczych niemieckiej policji ${ }^{42}$. Ważne jest jednak, aby badania uwzględniały całą skomplikowaną sytuację okupacyjną, w jakiej znajdowali się Polacy. Bez jej ukazania nie sposób rzetelnie opracować ten temat. W badaniach nad stosunkami polsko-żydowskimi na pewno należy starać się zachować obiektywizm, co oznacza, że właściwie każdy przypadek powinno się wnikliwie zanalizować wykorzystując do tego wszystkie dostępne źródła. W innym przypadku wyniki badań będą wzbudzały wiele emocji, a nie doprowadzą do merytorycznej dyskusji.

Reasumując. Historiografia polska o zagładzie i stosunkach polsko-żydowskich jest to temat bardzo obszerny, toteż jej przegląd w krótkim artykule nie wyczerpuje wszystkich poruszanych zagadnień. Nie uwzględniono w nim także wielu opracowań lokalnych, ponieważ po prostu brak o nich rzetelnych naukowych informacji. Można jednak stwierdzić, że wprowadzono do obiegu naukowego wiele nowych dokumentów, wspomnień i relacji, zajęto się problemami omijanymi dotąd, zwrócono uwagę na różne strony relacji polsko-żydowskich. Wciąż jednak stosunki polsko-żydowskie oraz wiele aspektów Zagłady Żydów pozostaje obiektem ostrych sporów.

\section{The outline of Polish historiography at the turn of the 20th and 21st centuries concerning the Extermination of Jews and Polish-Jewish relations}

\section{Summary}

This article is devoted to Polish historiography of the turn of the 20th and 21st centuries concerning the Extermination of Jews and Polish-Jewish relations. It presents the works of both Polish historians and representatives of other scientific disciplines published in Poland and abroad and the Polish translations of foreign scientists' works. Nevertheless, the article is mainly focused on the output of Polish historians because their contribution thereto is the greatest.

Since the end of the 20th century, many works devoted to the Extermination of Jews to a greater or lesser extent have been published. These include both works

\footnotetext{
i Materiały"... 2007, t. 7; A. Puławski, Wykluczenie czy samowykluczenie? Trzy aspekty obecności Żydów w wojennym społeczeństwie polskim na przykładzie 1942 r. „Pamięć i Sprawiedliwość” Pismo naukowe poświęcone historii najnowszej 2008, nr 1(12), s. 127-157; M. J. Chodakiewicz, Historia pewnego mordu, „Glaukopis” 2013, nr 29, s. 112-129.

42 Nadal jedynym opracowaniem poświęconym historii tzw. policji grantowej jest praca A. Hempla, Pogrobowcy klęski. Rzecz o policji ,grantowej” w generalnym Gubernatorstwie 1939-1945, Warszawa 1990. Regionalne studia oraz wspomnienia, w których znaleźć można informacje o postawach policjantów wobec Żydów także są nieliczne.
} 
giving the general outlook of the preparatory measures and mechanism of extermination of the Jewish population during the II World War and regional studies concerning the extermination of Jewish population in individual regions or localities in Poland under German occupation. The biographies of persons who affected the lives of thousands of people (not only the perpetrators of crimes but also the employees of Jewish administration) have been published, too. The latter has given rise to a discussion among historians as to the attitude of Jewish leaders towards their fellow-citizens and the invader's authorities. These publications also depict issues related to various activities undertaken by the Jewish authorities (both civil administration and ghetto police), which have been discussed by Polish historians.

One of the continuous concerns of Polish historians is the issue that has been studied since the end of the German occupation (penal liability of the perpetrators of crimes, the functioning of ghettos, extermination camps, labour camps and concentration camps, and the lot of Jews who were kept and murdered there). Only recently the issues pertaining to the Jewish resistance movement and the economic factors determining the Extermination of Jews in Poland under German occupation have become the subject matter of discussions and verifications. Since the end of the 20th century, Polish historiography has been much more focused on Polish-Jewish relations during the German occupation. However, studies and articles concerning this issue certainly do not exhaust the subject. Polish historiography is still searching for answers to questions concerning diversified attitudes of the Polish society towards Jewish population during the Holocaust and factors that determined these attitudes.

The review of various research concerning the Extermination of Jews and Polish-Jewish relations at the turn of the 20th and 21st centuries accomplished by Polish historians, which is presented in this article, shows that many new documents, memoirs and reports became then the subject matter of scientific examination and analysis, and matters that had long been ignored or consistently not mentioned for different reasons started to be discussed.

Key words: Poles, Jews, historiography, Extermination of Jews, Polish-Jewish relations

\section{Bibliografia}

Aleksiun N., Historiografia na temat Zagłady i stosunków polsko-żydowskich w okresie drugiej wojny światowej, „Zagłada Żydów. Studia i Materiały”. Pismo Centrum Badań nad Zagładą Żydów Instytutu Filozofii i Socjologii Polskiej Akademii Nauk, red. B. Engelking, J. Grabowski, D. Libionka, J. Leociak, Warszawa 2005, nr 1. 
Auerbach R., Treblinka. Reportaż, „Zagłada Żydów. Studia i Materiały”. Pismo Centrum Badań nad Zagładą Żydów Instytutu Filozofii i Socjologii Polskiej Akademii Nauk, red. B. Engelking, J. Grabowski, D. Libionka, J. Leociak, Warszawa 2012, nr 8.

Baranowski J., Chaim Mordechaj Rumkowski - kolaborant czy zbawca?, [w:] Zagłada Żydów na polskich terenach wcielonych do Rzeszy, red. A. Namysło, Warszawa 2008.

Bauman Z., Nowoczesność i Zagłada. Holocaust - choroba czy produkt cywilizacji? z oryginału przeł. T. Kunz, Warszawa 2009.

Bem M., Sobibór niemiecki ośrodek zagłady 1942-1943, Włodawa-Sobibór 2011.

Berendt G., Opór i zagłada żydowskiej ludności Turczyna (24 września 1942 r.), Pismo społeczno-historyczne „Glaukopis” 2012, nr 25-26.

Berendt G., Rewolta więźniów getta w Łachwie (3 września 1942), Pismo społeczno-historyczne „Glaukopis” 2011-2012, nr 23-24.

Blatt T. T., Z popiołów Sobiboru (skąd nie ma powrotu). Historia przetrwania, Włodawa 2002.

Böhler J., Mallmann K.M., Matthäus J., Einsatzgruppen w Polsce, z oryginału przeł. E. Ziegler-Brodnicka, Warszawa 2009.

Böhler J., Zbrodnie Wehrmachtu w Polsce. Wrzesień 1939. Wojna totalna, Kraków 2009.

Browning Ch. R., , Geneza „ostatecznego rozwiazania”. Ewolucja nazistowskiej polityki wobec Żydów. Wrzesień 1939-marzec 1942, z oryginału przeł. B. Gutowska-Nowak, Kraków 2012.

Browning Ch. R., Zwykli ludzie. 101 Policyjny Batalion Rezerwy I "ostateczne rozwiazanie" w Polsce, z oryginału przeł. P. Budkiewicz, Warszawa 2000.

Brzeziński M., Armia Izraela. Walka i opór polskich Żydów, z oryginału przeł. M. Habura, Kraków 2013.

Bunt w Sobiborze. Opowieść o przetrwaniu w Polsce okupowanej przez Niemców. Philip Bialowitz opowiada swojemu synowi Josephowi Bialowitzowi, red. nauk. R. Kuwałek, Warszawa 2008.

Chodakiewicz M. J., Historia pewnego mordu, Pismo społeczno-historyczne „Glaukopis” 2013, nr 29, s. 112-129.

Chodakiewicz M.J., Lonek Skosowski: Koniec żydowskich kolaborantów Gestapo, Pismo społeczno-historyczne „Glaukopis 2007-2008, nr 9-10.

Cukierman Y. (Antek), Nadmiar pamięci (siedem owych lat): Wspomnienia 1939-1946, z oryginału przeł. Z. Perelmuter Warszawa 2000.

Cyprys R. A., Skok dla życia: Pamiętnik z czasów okupacji, z oryginału przeł. E. Skweres, Warszawa 2001.

Cywiński M. A., Zagłada w pamięci więźniów Sonderkommando, Oświęcim 2015.

Datner Sz., zbrodnie hitlerowskie na Żydach zbiegtych z gett, „Biuletyn Żydowskiego Instytutu Historycznego" 1970, nr 3 (75).

Dean M., Gospodarka wyzysku: „warunki życia” w gettach na Kresach Wschodnich, , „Zagłada Żydów. Studia i Materiały”. Pismo Centrum Badań nad Zagładą Żydów 
Instytutu Filozofii i Socjologii Polskiej Akademii Nauk, red. B. Engelking, J. Grabowski, D. Libionka, J. Leociak, Warszawa 2007, nr 3.

Dobroszycki L., Polska historiografia na temat zagłady: przegląd literatury i próba syntezy, [w:] Holocaust z perspektywy półwiecza. Pięćdziesiąta rocznica powstania $w$ getcie warszawskim. Materiały z konferencji zorganizowanej przez żydowski Instytut Historyczny w dniach 29-31 marca 1993, red. D. Grinberg, P. Szapiro, Warszawa, b.d.w.

Drywa D., Zagłada Żydów w obozie koncentracyjnym Stutthof 1939-1945, Gdańsk 2001.

Engelking B., Grabowski J., „Żydów łamiących prawo należy karać śmiercią!”. „Przestępczość Żydów w Warszawie 1939-1942”, Warszawa 2010.

Engelking B., Jest taki piękny słoneczny dzień... Losy żydów szukających ratunku na wsi polskiej 1942-1945, Warszawa 2011.

Engelking B., Sny jako źródło do badań nad Zagłada, „Zagłada Żydów. Studia i Materiały”. Pismo Centrum Badań nad Zagładą Żydów Instytutu Filozofii i Socjologii Polskiej Akademii Nauk, red. B. Engelking, J. Grabowski, D. Libionka, J. Leociak, Warszawa 2013, nr 9.

Epstein C. Wzorcowy nazista. Arthur Greiser i okupacja Kraju Warty, z oryginału przeł. J. Włodarczyk, Wrocław b.d.w.

Ernest E., O wojnie wielkich Niemiec z Żydami w Warszawie 1939-1943, Warszawa 2003.

Friedländer S., Czas eksterminacji. Nazistowskie Niemcy i Żydzi 1939-1945,z oryginału przeł. S. Kupisz, A.M. Nowak, K. Masłowski, Warszawa 2010.

Giebułtowski J., Niech przemówią fakty. O polskim wydaniu Zagłady Żydów europejskich Raula Hilberga „Zagłada Żydów. Studia i Materiały” Pismo Centrum Badań nad Zagładą Żydów Instytutu Filozofii i Socjologii Polskiej Akademii Nauk, red. B. Engelking, J. Grabowski, D. Libionka, J. Leociak, Warszawa 2013, nr 9.

Gilbert M., Atlas historii Holocaustu, z oryginału przeł. M. Klimowicz, Kraków - Kryspinów, b.d.w.

Goldhagen D. J., Gorliwi kaci Hitlera. Zwyczajni Niemcy i Holocaust, z oryginału przeł. W. Horabik, Warszawa 1999.

Grabowski J., , Ja tego Żyda znam”. Szantażowanie Żydów w Warszawie 1939-1943, Warszawa 2004.

Grabowski J., Judenjagd. Polowanie na Żydów 1942-1945. Studium z dziejów pewnego powiatu, Warszawa 2011.

Grabowski J., Szantażowanie Żydów: casus Warszawy 1939-1945, „Przegląd Historyczny" 2008, t. XCIX, z. 4.

Greif G., ,... płakaliśmy bez łez...”. Relacje byłych więźniów żydowskiego Sonderkommando z Auschwitz, z oryginału przeł. J. Kapłon, Warszawa-Oświęcim 2001.

Grubowska H., Ta, która ratowała Żydów. Rzecz o Irenie Sendlerowej, Warszawa 2014.

Gutman I., Stosunki polsko-żydowskie w świetle żydowskiej historiografii i literatury, „Biuletyn Żydowskiego Instytutu Historycznego” 2000, nr 1 (193). 
Hempel A., Pogrobowcy klęski. Rzecz o policji ,grantowej” w generalnym Gubernatorstwie 1939-1945, Warszawa 1990.

Hilberg R., Zagłada Żydów europejskich, z oryginału przeł. J. Giebułtowski, Warszawa 2014, t. 1-3.

Katzmann F., Rozwiąanie kwestii żydowskiej w Dystrykcie Galicja, oprac. A. Żbikowski, Warszawa 2001.

Kazimierski J., Ludność żydowska w Warszawie w latach 1939-1943. Życie-walka-Zagła$d a$, Warszawa 2012;

Klucze i kasa. O mieniu żydowskim w Polsce pod okupacja niemieckq $i$ we wczesnych latach powojennych 1939-1945, red. J. Grabowski, D. Libionka, Warszawa 2014.

Koli A., Hitlerowski obóz zagłady w Bełżcu w świetle źródeł archeologicznych: badania 1997-1999, Warszawa-Waszyngton 2000,

Kopciowski A., Zagłada Żydów w Zamościu, Lublin 2005.

Kopka B., Koncetrationslager Warschau. Historia i następstwa, Warszawa 2007.

Kornbluth A., Jak wielu Kainów jest wśród nas" Polski wymiar sprawiedliwości a Zagłada, 1944-1956,s. 157-172; „Zagłada Żydów. Studia i Materiały”. Pismo Centrum Badań nad Zagładą Żydów Instytutu Filozofii i Socjologii Polskiej Akademii Nauk, red. B. Engelking, J. Grabowski, D. Libionka, J. Leociak, Warszawa 2013, t. 9.

Kosiński J., W. Sobczyk, Niemieckie obozy koncentracyjne i ich filie, b.m.w. 1999.

Kotarba R., Niemiecki obóz w Płaszowie, Warszawa-Kraków 2009.

Krempa A., Zagłada Żydów mieleckich, Mielec 2012.

„Kto w takich czasach Żydów przechowuje?...”. Polacy niosacy pomoc ludności żydowskiej w okresie okupacji niemieckiej, red. A. Namysło, Warszawa 2009.

Księga Pamięci. Transporty Polaków do KL Auschwitz z Krakowa i innych miejscowości Polski południowej, red. F. Piper, I. Strzelecka, Warszawa - Oświęcim 2002, t. 1-5.

Księga Pamięci. Transporty Polaków do KL Auschwitz z Lublina i innych miejscowości Lubelszczyzny 1940-1944, red. F. Piper, I. Strzelecka, Oświęcim 2009, t. 1-4.

Księga Pamięci. Transporty Polaków do KL Auschwitz z Radomia i innych miejscowości Kielecczyzny 1940-1944, red. F. Piper, I. Strzelecka, Warszawa-Oświęcim 2006, t. $1-5$.

Księga Pamięci. Transporty Polaków z Warszawy do KL Auschwitz 1940-1944, Warszawa-Oświęcim 2000.

Księga Sprawiedliwych wśród Narodów Świata. Ratujący Żydów podczas Holocaustu. Polska, Kraków 2009.

Księgi zgonów z Auschwitz, red. J. Dębski, S. Goldman, H. Jastrzębska, S. Kreuhage, J. Parcer, Oświęcim 1995, t. 1-3.

Kurek E., Gdy klasztor znaczył życie. Udział żeńskich zgromadzeń zakonnych w akcji ratowania dzieci żydowskich w Polsce w latach 1939-1945, Kraków 1992.

Kurek E., Poza granice solidarności. Stosunki polsko-żydowskie 1939-1945, Kielce 2006. 
Kuwałek R., Nowe ustalenia dotyczace liczby ofiar niemieckiego obozu zagłady w Sobiborze, ,Zeszyty Majdanka” 2014, t. XXVI.

Kuwałek R., Obóz Zagłady w Bełżcu, Lublin 2010.

Lesiakowski K., Z dziejów Zagłady w Kraju Warty. Losy ludności żydowskiej w Sieradzu 1939-1942, „Pamięć i Sprawiedliwość”. Pismo naukowe poświęcone historii najnowszej" 2014, nr 1 (23).

Libionka D., „Kwestia żydowska” w Polsce w ocenie Delegatury Rzadu RP i KG ZWZ-AK w latach 1942-1944, [w:] Zagłada Żydów. Pamięć narodowa a pisanie historii $w$ Polsce $i$ we Francji, red. B. Engelking, j. Leociak, D. Libionka, A. Ziębińska-Witek, Lublin 2006.

Libionka D., Narodowa Organizacja Wojskowa i Narodowe Sity Zbrojne wobec Żydów pod Kraśnikiem - korekta obrazu, „Zagłada Żydów. Studia i Materiały”. Pismo Centrum Badań nad Zagładą Żydów Instytutu Filozofii i Socjologii Polskiej Akademii Nauk, red. B. Engelking, J. Grabowski, D. Libionka, J. Leociak, Warszawa 2011, nr 7.

Libionka D., Weinbaum L., Bohaterowie, hochsztaplerzy, opisywacze. Wokót żydowskiego Związu Wojskowego, Warszawa 2011.

Lower W., Sprawcy i sprawczynie Zagłady a podejście do sprawiedliwości w NRD w latach 1949-1963, ,Zagłada Żydów. Studia i Materiały”. Pismo Centrum Badań nad Zagładą Żydów Instytutu Filozofii i Socjologii Polskiej Akademii Nauk, red. B. Engelking, J. Grabowski, D. Libionka, J. Leociak, Warszawa 2012.

Madaj K., Żuławnik M., Proboszcz z getta, Warszawa 2010.

Marszałek J., Obozy pracy w Generalnym Gubernatorstwie w latach 1939-1945, Lublin 1998.

Melchior M., Zagłada i stosunki polsko-żydowskie w opracowaniach socjologicznych, „Zagłada Żydów. Studia i Materiały”. Pismo Centrum Badań nad Zagładą Żydów Instytutu Filozofii i Socjologii Polskiej Akademii Nauk, red. B. Engelking, J. Grabowski, D. Libionka, J. Leociak, Warszawa 2005, nr 1.

Mędykowski W., Przeciw swoim. Wzorce kolaboracji żydowskiej w Krakowie i okolicy, „Zagłada Żydów. Studia i Materiały”. Pismo Centrum Badań nad Zagładą Żydów Instytutu Filozofii i Socjologii Polskiej Akademii Nauk, red. B. Engelking, J. Grabowski, D. Libionka, J. Leociak, Warszawa 2006, nr 2.

Michman D., O okolicznościach ustanowienia warszawskiego Judenratu. Nowy punkt widzenia, „Kwartalnik Historii Żydów” 2007, nr. 1.

Młynarczyk J. A., pomiędzy współpracą, a zdradą. Problem kolaboracji w Generalnym Gubernatorstwie - próba syntezy, „Pamięć i Sprawiedliwość”. Pismo naukowe poświęcone historii najnowszej 2009, nr 1(14).

Młynarczyk J. A., Judenmord in Zentralpolen. Der Distrikt Radom im Generalgouvernek ment 1939-1945, Darmstadt 2007.

Montaque P., Chełmno. Pierwszy nazistowski obóz zagłady, z oryginału przeł. T. S. Gałązka, Warszawa 2014. 
Musiał B., Deutsche Zivilverwaltung und Judenverfolgung im Generalgouvernement. Eine Fallstudie zum District Lublin 1939-1944, Wiesbaden 1999.

Namysło A., Centrala żydowskich Rad Starszych na Wschodnim Górnym Śląsku [w:] Zagłada Żydów Zagłębiowskich, red. A. Namysło, Będzin 2004.

Obozy hitlerowskie na ziemiach polskich 1939-1945. Informator encyklopedyczny, Warszawa 1979.

Obóz Zagłady w Bełżcu $w$ relacjach ocalonych i zeznaniach polskich świadków, red. D. Libionka, Lublin 2013.

Orski M., Niewolnicza praca więźniów obozu koncentracyjnego Stutthof w latach 19391945, Gdańsk 1999.

Paul M., Donosiciele i szabrownicy w okupowanej Warszawie (1939-1944), Pismo społeczno- historyczne „Glaukopis” 2012, nr 27.

Paul M., Polskie podziemie a Żydzi. Korekta obrazu, Pismo społeczno-historyczne „Glaukopis" 2012, nr 25-26.

Peczerski A., Szturm w nieśmiertelność. Wspomnienia, Warszawa 2013.

Perechodnik C., Spowiedź, Warszawa 2011.

Peterson K., Mówi Jürgen Stroop. Proces likwidatora powstania w getcie warszawskim przed Sąem Wojewódzkim w Warszawie, „Zagłada Żydów. Studia i Materiały”. Pismo Centrum Badań nad Zagładą Żydów Instytutu Filozofii i Socjologii Polskiej Akademii Nauk, red. B. Engelking, J. Grabowski, D. Libionka, J. Leociak, Warszawa 2013, t. 9.

Piątkowski S., Udziat niemieckiej żandarmerii w eksterminacji ludności żydowskiej Generalnego Gubernatorstwa (na przykładzie pótnocno-wschodniej części dystryktu radomskiego, [w:] Zagłada Żydów na polskiej prowincji, red. A. Sitarek, M. Trębacz, E. Wiatr, Łódź 2013.

Pohl D., „Akcja Reinhardt” w świetle historiografii, [w:] Akcja Reinhardt. Zagłada Żydów w Generalnym Gubernatorstwie, red. D. Libionka, Warszawa 2004.

Polacy $i$ Żydzi pod okupacją niemiecka 1939-1935. Studia i materiały, red. A. Żbikowski, Warszawa 2006.

Polit M., „Moja żydowska dusza nie obawia się dnia squdu”. Mordechaj Chaim Rumkowski. Prawda i zmyślenie, Warszawa 2012.

Potocki A., Żydzi rymanowscy, Krosno 2000.

Prowincja noc. Życie i zagłada Żydów w dystrykcie warszawskim, red. B. Engelking, J. Leociak, D. Libionka, Warszawa 2007.

Prusin A. V., Polska Norymberga: siedem procesów przed Najwyższym Trybunałem Narodowym, 1946-1948, „Zagłada Żydów. Studia i Materiały”. Pismo Centrum Badań nad Zagładą Żydów Instytutu Filozofii i Socjologii Polskiej Akademii Nauk, red. B. Engelking, J. Grabowski, D. Libionka, J. Leociak, Warszawa 2013, t. 9.

Przybyłowicz K., Żydzi Biecza. Historia i Zagłada, Gliwice-Libusza 2015. 
Puławski A., Postrzeganie żydowskich oddziałów przez armię Krajowa i Delegaturę Rzqdu na Kraj „Pamięć i Sprawiedliwość” 2003, nr 2.

Puławski A., Wykluczenie czy samowykluczenie? Trzy aspekty obecności Żydów w wojennym społeczeństwie polskim na przykładzie 1942 r., Pamięć i Sprawiedliwość". Pismo naukowe poświęcone historii najnowszej 2008, nr 1(12).

Rączy E., Pomoc Polaków dla ludności żydowskiej na Rzeszowszczyźnie 1939-1945, Rzeszów 2008.

Rączy E., Witowicz I., Polacy ratujący Żydów na Rzeszowszczyźnie w latach 1939-1945 (Poles Rescuing Jews in the Rzeszów Region in the Years 1939-1945, Rzeszów 2011.

Rączy E., Witowicz I., Zagłada Żydów na Rzeszowszczyźnie. Album pamięci. (Extermination of Jews in the Rzeszów Region, Rzeszów-Warszawa 2004.

Rączy E., Zagłada Żydów w dystrykcie krakowskim 1939-1945, Rzeszów 2014.

Relacje z czasów Zagłady. Inwentarz, t. I - VII, 1998-2011.

Riedel J., Postepowania karne w Niemczech w procesach o eksterminacje Żydów na polskich ziemiach wcielonych do Rzeszy. Zarys problemu [w:] Zagłada Żydów na polskich terenach wcielonych do Rzeszy, red. A. Namysło, Warszawa 2008.

Rieger B., Odilo Globocnik. Twórca nazistowskich obozów śmierci, z oryginału przeł. J. Zaus, Poznań 2009.

Roth M., Starostowie powiatowi i zagłada Żydów w dystrykcie krakowskim Generalnego Gubernatorstwa, [w:] Zagłada Żydów na polskiej prowincji, red. A. Sitarek, M. Trębacz, E. Wiatr, Łódź 2013.

Sachslehner J., Kat z listy Schindlera. Zbrodnie Amona Leopolda Götha, Kraków 2010.

Serena G., W stronę ciemności. Rozmowy z komendantem Treblinki, z oryginału przeł. J. K. Milencki, Warszawa 2002.

Silberklang D., Refleksje na temat losu Żydów w okupowanej Polsce 1939-1945, przeł. A. Matulewska, „Pamięć i Sprawiedliwość”. Pismo naukowe poświęcone historii najnowszej 2008, nr 1(12).

Sitarek A., Rola niemieckiego zarząu getta $w$ Łodzi $w$ eksterminacji gett prowincjonalnych Kraju Warty, [w:] Zagłada Żydów na polskiej prowincji, red. A. Sitarek, M. Trębacz, E. Wiatr, Łódź 2013.

Sitarek A., Otoczone drutem państwo. Struktura i funkcjonowanie administracji żydowskiej getta łódzkiego, Łódź 2015.

Stanisławski W., T. Terlikowski, Rumkowski, Czerniaków-życiorysy równolegle, „Życie” 2004, 14 października.

Steinlauf M. C., Pamięć nieprzyswojona. Polska pamięć Zagłady, z oryginału przeł. A. Tomaszewska, Warszawa 2001.

Stroop J., Żydowska dzielnica mieszkaniowa $w$ Warszawie już nie istnieje, oprac. A. Żbikowski, Warszawa 2009. 
Sturdy Colls C., O tym, co minęło, lecz nie zostało zapomniane. Badania archeologiczne na terenie byłego obozu zagłady w Treblince, „Zagłada Żydów. Studia i Materiały”. Pismo Centrum Badań nad Zagładą Żydów Instytutu Filozofii i Socjologii Polskiej Akademii Nauk, red. B. Engelking, J. Grabowski, D. Libionka, J. Leociak, nr 8.

Szapiro P., Prasa konspiracyjna jako źródło do dziejów stosunków polsko-żydowskich w latach II wojny światowej - uwagi, pytania, propozycje badawcze, „Biuletyn Żydowskiego Instytutu Historycznego" 1988, nr 3-4 (147-149).

Szczęsna J., Reduta Adama Czerniakowa, „Gazeta Wyborcza” 21-22 września 2002.

Szurek J. Ch., Proces Gustava Wilhelma Trappa, „Zagłada Żydów. Studia i Materiały”. Pismo Centrum Badań nad Zagładą Żydów Instytutu Filozofii i Socjologii Polskiej Akademii Nauk, red. B. Engelking, J. Grabowski, D. Libionka, J. Leociak, Warszawa 2013, nr 9.

Szurek J.-C., Proces Gustava Wilhelma Trappa, „Zagłada Żydów. Studia i Materiały”. Pismo Centrum Badań nad Zagładą Żydów Instytutu Filozofii i Socjologii Polskiej Akademii Nauk, red. B. Engelking, J. Grabowski, D. Libionka, J. Leociak, Warszawa 2013, t. 9.

Szymańska S., Ludność żydowska w Otwocku w czasie II wojny światowej, Warszawa 2002.

Tal B., Sądzenie tych, którzy nie mogli być sądzeni. Procesy kolaborantów w Izraelu, „Zagłada Żydów. Studia i Materiały”, Pismo Centrum Badań nad Zagładą Żydów Instytutu Filozofii i Socjologii Polskiej Akademii Nauk, red. B. Engelking, J. Grabowski, D. Libionka, J. Leociak Warszawa 2006, nr 2.

Tomaszewski J., Historiografia Polska o Zagładzie, „Biuletyn Żydowskiego Instytutu Historycznego" 2000, nr 2 (194).

Urbański K., Zagłada Żydów w dystrykcie radomskim, Kraków 2004.

Urynowicz M., Adam Czerniaków 1880-1942. Prezes getta warszawskiego, Warszawa 2009.

Urynowicz M., Listy o Zagładzie. Kryptoinformacja, „Pamięć i Sprawiedliwość”. Pismo naukowe poświęcone historii najnowszej 2002, nr 1 (1).

Venezia S., Sonderkommando. W piekle komór gazowych, przeł. K. Szeżyńska-Maćkowiak, Warszawa 2009.

Wokót Jedwabnego, red. P. Machcewicz, K. Persak, Warszawa 2002.

Wolniewicz B., Fikcyjne 10\% czyli ilu Żydów zabili Polacy?, Pismo społeczno- historyczne „Glaukopis” 2012, nr 25-26.

Wrniszewscy D. A., ... Aby żyć, „Kontakty” Łomżyński Tygodnik Społeczny 1988, nr 27 (403).

Zagłada Żydów na polskich terenach wcielonych do Rzeszy, red. A. Namysło, Warszawa 2008.

Zagłada Żydów Zagłębiowskich, red. A. Namysło, Będzin 2004. 
Zarys krajobrazu. Wieś polska wobec Zagłady Żydów 1942-1945, red. B. Engelking, J. Grabowski, Warszawa 2011.

Ziółkowska A., Obozy pracy przymusowej dla Żydów w Wielkopolsce w latach okupacji hitlerowskiej (1941-1943), Poznań 2005.

Zrozumieć Zagładę. Społeczna psychologia Holocaustu, red. L. S. Newman, R. Erber, z oryginału przeł: M. Budziszewska, A. Czarna, E. Dryll, A. Wójcik, Warszawa 2009.

Żbikowski A., Sąd Społeczny przy CKŻP. Wojenne rozliczenie społeczności żydowskiej w Polsce, Warszawa 2014.

Żbikowski A., U genezy Jedwabnego. Żydzi na Kresach Pótnocno-Wschodnich II Rzeczpospolitej, wrzesień 1939-lipiec 1941, Warszawa 2006.

Żbikowski,A. .Lokalne pogromy Żydów w czerwcu i lipcu 1941 roku na wschodnich rubieżach II Rzeczypospolitej, nr 2-3 (162-163), IV-IX 1992.

Żydzi polscy w KL Auschwitz. Wykazy imienne, Polish Jews in KL Auschwitz. Name lists, oprac. S. Mączka, Warszawa 2004. 